John G. Gibson $\quad$ IRSS 36 (2011)

93

\title{
A Blind Perthshire Sergeant's Lament for his Golonel WHO Died at El HAMET in 1807
}

\author{
John G. Gibson*
}

In the Fall of 2010 a long-overlooked and unpublished marbhrann came to light in the papers of the MacLeods of Geanies held by the National Library of Scotland (NLS MS.19302), Marbhrann Chornail MhicLeoid Chuaidh Mharbhadh aig El hamed san Ephait/ Death-verse of Colonel MacLeod who was killed at El Hamet in Egypt. The author was "Alexander Forbes late Sergeant. 78 ${ }^{\text {th }}$ Highlanders." The verses are presented under the English heading "Gaelic Poem by a Blind Man who had been a Serg ${ }^{t}$ in $78^{\text {th }}$ Reg $^{\mathrm{t}}$. Translated by $\mathrm{M}^{\mathrm{r}}$ Forbes. [Rev. William Forbes?]." The lament's discovery doubles the known output of the author and adds not insignificantly to the corpus of Perthshire bàrdachd.

The lament was composed in 1808 and is given below in type-script almost as it appears, to me, in the original. The quill hand-writing is not the author's. Even with the writer's idiosyncratic use of apostrophes/commas, the absence of accents, and occasional apparently uncrossed ' $t$ 's, most is

*John G. Gibson, MA (1964), PhD (2002) (by research publications) is the author of Traditional Gaelic Bagpiping, 1745-1945 (MQUP and National Museum of Scotland, 1998), Old and New World Highland Bagpiping (MQUP, 2002) and Back o' the Hill (Birlinn, 2008). Of importance is his work in establishing the significance of cultural anachronisms still existing uniquely in the Cape Breton Gaidhealtachd into the 1970s, elements of which persist. He was awarded a John Simon Guggenheim fellowship in 2005 for work on traditional Scotch Gaelic step-dancing and it is in this area that he is currently researching and writing. 
readily understandable, but there are points which need attention.

The work is followed by Alexander Forbes's accompanying letter to a sister of Patrick MacLeod's, the contemporary translation by "Mr Forbes" and then by a deliberately more literal, modern version in my English. I am very grateful to Dr Ulrike Hogg (senior curator of mss at NLS) for her kind help in delivering to me digital copies of the original song, and many of her thoughts on the subject, electronically. And through Dr Hogg I was fortunate in finding the assistance of emeritus professor Dr Colm Ó Baoill of Aberdeen University.

MacLeod's commissioned career was spent in three battalions of two Scottish Highland regiments, the $42^{\text {nd }}$ (Black Watch, from 1790), the second battalion $78^{\text {th }}$ (Ross-shire Highlanders, 1794), and then the second second battalion $78^{\text {th }}$ of which he was made lieutenant-colonel at its raising in 1804 . He was killed two days after his thirty-first birthday while trying to unite his three outpost detachments near the canalbank village of El Hamet on 21 April 1807. (El Hamad, in 1818, was on the north side of the canal, contrary to the often repeated statement that it lay to the south).

Mehmet Ali's mostly Turkish and Albanian forces, cavalry and infantry, appeared in overwhelming numbers in the dawn hours of that day from a flotilla of shipping that had sailed north from Cairo to take out the British outposts and to relieve their defence of Rosetta which the main British force was besieging.

MacLeod's three posts were spread evenly east-west to the north of the raised canal banks over an isthmus of mile and a half of good cavalry land --- they were at the Nile end (Bolbiton branch), at El Hamet, and at the Lake Edko end. Of the about seven hundred soldiers involved only three companies of MacLeod's 78 ${ }^{\text {th }}$ were there, perhaps two hundred men. At dawn MacLeod knew he was doomed. He was cut off from Rosetta, about four miles to the north. His 
only hope was to bring his detachments together and there wasn't the time. The Edko and El Hamet detachments were attacked first by cavalry, then after they had coalesced near El Hamet, were nearly obliterated by infantry and cavalry.

Where the author "Alexander Forbes" is concerned, WO97/886/62 (Royal Chelsea Hospital material), shows that an Alexander Forbes of the $2^{\text {nd }}$ battalion $78^{\text {th }}$ Highlanders was discharged at Fort George, by Inverness, on 22 November 1809 aged twenty-seven --- at that time he served in Sir Orford Gordon's company. He stood 5'6 1/2", had fair hair and complexion and grey eyes. He had become blind in England in 1808. His total service, from 4 July 1804 till 22 Nov. 1809, included 141 days as a private and 4 years and 325 days as sergeant (for a total of five years and 141 days: 4 July 1804-22 Nov. 1809). In his discharge he is described as a merchant, elsewhere (WO120/28) as a "labourer." He was born in the parish of Perth and was twenty-two when he enlisted. Although blind, he signed his own name quite elegantly in 1809 .

Almost certainly the same man, "Alastair Foirbeis," appears in Paul Cameron's "The Gaelic songs of Perthshire and their composers," TGSI 17 (1890-91, pp 158, 159). Here he is the composer of "Oran do Chornail Daibhidh Stiubhart, Triath Ghart," Song to colonel David Stewart, laird of Garth.

Cameron described him as, "Alastair Foirbeis, Bha Alastair na sheairtsean, anns an Fhreiceadan-Dhubh An deigh dha an t-arm fhagail, bha e fanachd 'am Fas re ioma bliadhna. Chaochail e ' am Peairt/ Alastair Forbes, Alastair was a sergeant in the $42^{\text {nd }}$ When he left the army he was living in Foss for many years He died in Perth. In his Song to David Stewart he wrote of Maida, ...Bha an tri fichead's a h-ochd deug ann, Na treun-fhir ri'd chluais/The $78^{\text {th }}$ were there, the brave lads at your side. David Stewart, who almost certainly recruited Forbes in 1804, took a step in promotion to major in Patrick MacLeod's 2/78 in 1804. The Chelsea hospital record and the discharge documents make no mention of any service of Alexander Forbes in the $42^{\text {nd }}$, 
and recruiting for MacLeod's 2/78 was going on as early as May 1804.

Marbhrann Chornail MhicLeoid Chuaidh Mharbhadh aig El hamed san Ephait.

"1 1 st Righ gur mis tha fo' eislean

Bho la chualas n' sgeula

Thug a phacait o'n Ephait

Ann n' toiseach a Cheitean

Gu'n do chaileadh Ceann feadhna na'n Gaidheal

$2^{\text {nd }} \quad$ Co a chi mo shuil dheurach

$S$ a their gu bheil sud gu'n reusan

Sa luithad la bha mi n' eibhneas

Fo'd chommanda' a threun fhir

Och na'n och S mi bhiodh eatrom ri'd shailtibh

$3^{\text {rd }} \quad$ Nuair a ghluais thu gu h'ordail

Moir'e b'olc chuaidh ordach

Chuirte' pairt do gach seor's leat

De Rolls s, gach prod

A bha aca gu'n sgoid a n sa Champa

$4^{\text {th }} \quad$ Mo chreach leir mur $a^{\prime}$ dheirich

Nach deach do Reisamaid fein leat

Ni tiomlan gu leir dhiu

Sa robh Thurcich sa'n Ephait

Na dhiana' do reubadh le h'aineart

$5^{\text {th }} \quad$ Aig El-hamed a' chruadail

Sa'n a chuaidh do chuartach

Mar leomhan n' bualead

S gu'n bhi agad ri'd ghuailibh

Na seoid dheanadh fuasgladh gun taing ort 
John G. Gibson IRSS 36 (2011)

$6^{\text {th }} \quad$ S math chum thu a' chomhail

$S$ cha robh u baileach a' $t$ ' onar

$\mathcal{N a}$ Granadiers bha riut comhla

An' ta riamh bha do dhochas

$S$ thuit iad uille s b'e bron e do'n cairdean

$7^{\text {th }} \quad$ Ach se sgar uile bho'm cheil mi

Gu'n thuit n Cornail s nach deirich

$S$ ged a tha mi gu'n leirsin*

Cha n'e s sinn tha cuir eis orm

Ach n' diu bhi a's eugais do chairdeas

$8^{\text {th }} \quad$ Tha do Reisamaid dubhach

Gach aon diu ga'd chumha'

Dheagh Mhicleoid n'am suidhe

Ann $s$ gach ait $m$ bi buidhean

[the ' $t$ ' in 'ait' is uncrossed]

$S$ tric do sgeulsa ga bhruithin mu'n bhord

$9^{\text {th }} \quad$ Cha robh leighich ra fhaoitin

A chaisge t fhuil chraobhach

$S$ i ruith bhuait na taomabh

[the ' $t$ ' in 'bhuait' is uncrossed]

Gur e sud thug $n$ aois orm

Do chorp glann a' bhi faoin ann sa n' airich

$10^{\text {th }} \quad$ Mar Long mhor air cuan arda

Gu'n stiur gun chrannabh gun chabuil

Gun a h'acrichin bais aic

So sud coimeas Fear Ghainn

S nach maireann thus' Phadric ga sheoladh

$11^{\text {th }} \quad$ Tha do pheathraichean suairce

Duint' n'an seomrichean uaigneas

$S$ mor a chaoinil n sornadh dhiu'

$S$ tric na deoir ruith o'n gruaidhean

$S$ beag iodhna mo thruaidhe mu'n Braithir 
$12^{\text {th }} \quad$ Nuair a rachadh tu fhiadhach

Leis a ghunna gun ghiamh ann

Bhiodh do ghillin gu t'iartas

Loinn chonn leat air iallabh

Chuireadh fuil air damh riabhach n'an ard bheann

$13^{\text {th }}$ Ach tha $n$ ruadh bhoc sa'n eilid

Chleach bhi gealtach roimh d theine

$S$ am breac air n linne

$\mathcal{N}$ ise luanach gun ghiorag

Cha chuir u armuin chaoidh tuille bonn sga or'

$14^{\text {th }} \quad$ S truagh nach $b$ urrainn mi inseadh

No idir a sgriobhadh

Gach buaidh bha riut sinte

$O$ ! chan urrain gu dillinn

$B$, ard a choille $n$ do chinn, $n$ tog aluinn

[the ' $t$ ' in ' $t o g$ ' is uncrossed]

$15^{\text {th }} \quad \mathcal{N}$ siormach'd Rois a chuaidh t'arach

$S$ cha b ann a chinne bu taire

Siol Leoid n'an arm staillinne

$S$ tric rinn sgathath sna blarabh

Mo chreach gu'n iad laimh riut sa' n'do' uair

$16^{\text {th }} \quad$ A thi a dh'orduich gach seasan

Gach cogadh s reubainn

$S$ ann duit s, aithne gach creutair

Tha mi n' dochas ad threun laimh

Gu m bheil mo Chornail lann eibhneis n’ parrais

N.B The last line of every verse to be sung twice over.

*The composer being realy blind" 
NB. Lt-col MacLeod's 2/78 were exposed to an ophthalmia while in Sicily in late 1806. According to David Stewart (Sketches, vol. 2, pp. 311, 320, 321) it was brought there then by general John Moore's men, fresh from England where the disease had persisted and been spread by veterans of the 1801 campaign against the French at Alexandria. In WO12/8375 a sergeant Alexander Forbes is on record as "recruiting" during the period 25 March to 21 April 1807. He had been transferred from Donald MacKenzie's company of 2/78 to captain MacGregor's company. If this is the man he missed El Hamet and brigadier-general William Stewart's failed siege of Rosetta in April 1807.

The lament's author also wrote:

Madam,

Motives of delicacy prevented me from sending you the forgoing lines before this time, having composed them immediately after that unfortunate expedition had returned from Egypt. I have at length come to a resolution of laying them before you which I sincerely hope will not displease you, although the verses may not be found a very poetical production. I beg leave to say that they are the humble dictates of a heart sincerely attached to the late Colonel P. MacLeod $2^{\text {nd }}$ Battalion $78^{\text {th }}$ Highlanders in which corps I was serjeant but now am an out Pensioner of Chelsea Hospital being discharged on account of blindness. This want of sight will therefore account for the inaccuracy of the prefixed poem, the composer himself not being able to write or correct the copy.

Should this small testimony of esteem for your brother find favour in your light: be pleased to acknowledge the receipt of it by a few lines from your 
hand which I shall esteem in the greatest favour that could be conferred upon me.

And I am

Madam with the greatest respect your most obedient \& humble servant

Alex Forbes

Late Sergeant

$78^{\text {th }}$ Highlanders

PS direct to me at Drumacharry care of Robert Stewart

Esq $^{r}$ Gairth" [Robert Stewart, father of above David

Stewart, died in 1820].

A translation of the above is given under the heading "Lines on the death of Col. McLeod by Stranger to his Family name un=known to me ---[unclear signature in abbrev. "C. McL"]":

"An Elegy for Col. MLeod who was killed at el hamet in Egypt

1. I am truly distressed, since I heard the report brought by the Packet from Egypt on the beginning of Spring, that the Chief or Commander of the Highlanders is dead.

2. Who sees my tearful eye, and will say that my grief is unreasonable: and so many Days as I was joyful under the Command of the Hero. Alas Alas I was wont to be cheerful attending you

3 When you moved on regularly, according to an injudicious Order. A part of each Corps which they had in the Camp was sent with you De Rolls \&c

4 Alas! How it happen'd that all your own Reg ${ }^{\text {did }}$ not accompany you, considering the Number of Turks in Egypt ready to destroy you by their superior forces.

5 At ill-fated El hamed you was surrounded as a Lion in a Fold or [indistinct], and none of the Chiefs near to release you. 
6 Well did you keep the appointment and you were not quite alone --- the Grenadiers, in whom you always put confidence, attended you and they all fell to the Grief of their Friends.

7 But what separated me from my beloved, is that the $\mathrm{Col}^{l}$ fell to rise no more And though I am blind, this distresses me not so much as to be deprived of your Friendship

8 Your Regiment is sorrowful each one laments you Excellent MacLeod And when Company meet, your History is often rehearsed at the table.

9 No physician could be found to stop the current of your blood as it ran [that's what aged me your innocent body lonely on the field]

10 Geanies resembles a stately Vessel on a boisterous sea, without rudder, masts, cable or Death ankers and $\mathrm{O}$ Patrick thou remainest not to direct

11 The appearance of your discreet sisters is much changed while shut in their chambers, they shed copious tears (no wonder! Alas for their Brother.

$12 \& 13$ When you went to hunt \&

14 I regret that my tongue or pen can never express the good properties of this excellent youth

15 In Ross-shire thou wast born and of no ordinary clan the warlike race of MacLeod, who often were renown'd in the Field. Alas that none of them was by you in the evil hour

16 O Thou almighty Being who appointed the seasons of war and plunder To this every creature is known: I trust that my Colonel enjoys perfect happiness in Paradise

N.B. In two or three of the verses the orthography is so incorrect that I can not give their meaning W.Fo...

Drumacharry $20 \ldots \ldots . .18 \ldots$ 
The three verses which need attention, by my lights, are 3, 13, and 14 and they are given with accents and punctuation added, then with C. Ó B's translations (bar the first line) and explanations.

\author{
Nuair a ghluais thu gu h-òrdail, \\ Moire, b'olc chuaidh, òrdach: \\ Chuirte pairt do gach seòrs leat \\ De Rolls is gach pròd \\ $A$ bha aca gun sgòid anns a' champa \\ Ach tha'n ruadh bhoc sa'n eilid \\ Chleach bhi gealtach roimh'd theine, \\ $S$, am breac air n' linne \\ N'ise luanach gu'n ghiorag: \\ Cha chuir u' àrmuin chaoidh tuille bonn sgàtha orra. \\ S, truagh nach b'urrainn mi innseadh \\ Na idir a sgriobhadh \\ Gach buaidh bha riut sinte \\ $O$ ' chan urrain gu dilinn \\ $B$, ard a choille'n do chinn, an t-òg aluinn.
}

In verse 3 the exclamative Moire is unusual inasmuch as it is normally used vocatively, 'Mhoire, by Mary. The nominative use may have been a district phenomenon. And, also according to Colm Ó Baoill, the word prod corrected to pròd is probably from bròd with a negative sense of 'brood.' The intent of the verse is to present a (or the) obvious reason for what was one of Britain's more surprising, minor military disasters. How much Alexander Forbes was aware of criticism of MacLeod's reaction to what was an overwhelming Ottoman force is unknown. 
[When you moved in regular fashion]

By Mary, the ordering went badly:

Part of every kind was sent with you

De Roll's and every shirtless bunch

Which they had in the camp.'

But the red buck and the hind,

Which were always afraid of your fire,

And the trout in the pool

Are now frisky and untroubled:

You, the hero, will never again cause them the slightest fear.

It is a pity that I cannot narrate, Or indeed write down

All the virtues which belonged to you:

Oh, I will never be able to do so:

Tall was the wood in which the handsome youth grew.

1. Lord, it's I who grieve since the day the Packet brought the news from Egypt in early May that the chief of the Gael was lost

2. Who will see my tearful eye and say that that's without reason and I so many joyous days under the brave man's command. Och nan och, t'was I'd be carefree in your service

3. When you moved regularly, by Mary, evil was the order that sent you a part of each regiment, De Roll's and every shirtless brood they had in the camp [Do gach --- de gach. Sgòid --- from Perthshire Gaelic. The old use of Roman Catholic terms like Mhoire! \{by Mary! $\}$ in the late $18^{\text {th }}$ century was common.] 4. My utter distress how it happened that your own regiment wasn't with you in their full strength and the 
Turks in Egypt ready to pull you apart with violence [Mur ---mar.]

5. At El Hamed of the distresses, there were you surrounded, like a lion in a cage, and without the warriors at your shoulder who'd free you unbidden 6. Well did you keep the appointment and you were not completely alone the Granadiers were with you in whom ever was your hope and they fell all, and, sorrowing are their friends

7. But what parts me completely from my senses [is] that the colonel fell to rise no more and though I am blind it's not that that troubles me but today to be without your friendship

8. Your regiment is melancholy each one of them laments you, good MacLeod in the time of heroes [saoidh, Perthshire?] wherever be company, oft will your tale be told around the board

9. There was no doctor to be had to staunch your gushing blood and it flowing from you in torrents that's what put ages on me your body lonely in the plain 10. Like a great ship on tall seas, with no steering, no masts, no cable, no death anchors [stones?], that's the image of Fear Ghainn and you Patrick dead and not there to sail her

11. Your courtly sisters shut in their lonely rooms great the change in their appearances often run the tears down their cheeks 'tis little surprise, woe for their brother

12. When you'd go hunting with the unblemished gun your steed at your command, a line[?] of dogs with you on leashes you'd blood the wild stag of the tall mountain 13. But the red buck and the hind that used to be fearful before your fire and the trout in the pool now [are] mercurial, fearless You, noble hero, no more will give them cause for dread

14. Sad am I that I can not tell nor even write of each 
John G. Gibson I IRSS36 (2011)

virtue [victory?] that came to you, and never may I stately the wood where you, the fine youth was raised 15. In Ross-shire you were raised and without reproach was your clan Children of Leod of the steel weapons that often cut down [the foe] on the field Alas they were not with you in your hour of need

16. O Lord who order each season, each war and plundering You who know each creature My trust in Your strong hand is that my colonel is in perfect happiness in Paradise. JGG.

\section{Addenda:}

The Church of Scotland minister of the parish of Tarbat in the presbytery of Tain from 1800 till 12 May 1838 was William Forbes AM (Aberdeen) (1767-1838). He was an excellent Gaelic preacher who had served as minister to the Gaelic chapel in Aberdeen (1798-1800). He is not included in Hew Scott's Fasti but is the "W. Forbes," minister of Tarbat c.1825 in Moral Statistics of the Highlands and Islands ... Inverness, 1826, p. 68. Mr Forbes, for whatever reasons, chose to omit translation of the religious reference in verse three, and the two verses that contain the Gaelic hunting imagery.

The sense of "reubadh," pulling apart in verse four is pointed for it was the failure of MacLeod's three-sided square moving eastwards from El Hamed to join the Nile square that was all but destroyed. MacLeod had ridden to and rallied the Etko post companies (including his grenadier company of $2 / 78$ ) and, with the northerly canal wall as protection on their right flank, joined with the El Hamet post in the centre --- the desperate threat that they had so far faced, and beaten off, was Mehmet Ali's cavalry, but squares dealt well with outnumbering cavalry.

By the time the two westerly groups coalesced, the main body from the Nile, including two companies of $2 / 78$, 
had moved inland out of the range of any ship-based canonry. It was only hundreds of yards away from the merged body near El Hamet when the hammer fell. Now, with about three hundred men MacLeod continued to rely on the tall canal bank for protection in the south --- he was confident that the swarming Ottoman cavalry could still be resisted. But then the enemy infantry arrived, scaled the northern canal wall and fired into the heart of the three-sided square. There MacLeod died and nearly all of his three hundred men. [NB At least two of the Grenadiers of 2/78 from the Etko post survived, captain Colin Campbell MacKay and sergeant Alexander Waters].

The only other song written by sergt Alexander Forbes is Oran do chornail Daibhidh Stiubhart, triath Ghart/ Song to colonel David Stewart, Laird of Garth. It is published in Transactions of the Gaelic Society of Inverness in the first of two parts of Mr Paul Cameron's "The Gaelic Songs of Perthshire and their composers" (TGSI, vol. 17 \{1890-1891\}, pp 158 and 159. Foss lies west of Loch Tummel and to the south of river Tummel in Perthshire. It was in the Church of Scotland parish of Dull. Alexander Forbes's religion is not known, but in 1829, the commissioners for the late David Stewart provided for ground for a manse and glebe at Foss (NAS GD112/51/228). The Old Statistical Account of the 1790s shows that there were four schools in the parish of Dull.

From a musical point of view Foss is remembered by the third placing of Peter Forbes from there in the Edinburgh classical piping competition of 1805. He was second in 1808 and first in 1809. And where Gaelic is concerned, it is known that David Stewart spoke the language, this marbhrann is one among several reasons to suppose that Patrick MacLeod did also. 